\title{
ISLAMIC BOARDING SCHOOLS TOWARD THE INDUSTRIAL REVOLUTION 4.0; OPPORTUNITIES AND CHALLENGES
}

\author{
Fanani Mafatikul Ihsan \\ Fanai23@gmail.com \\ Pramudia Yuly Eka Permana \\ Pramudi13@gmail.com \\ Nur Rachmat Arifin \\ Universitas Airlangga (Unair) Surabaya \\ fanani.mi@gmail.com \\ Ridan Muhtadi \\ STAI Miftahul Ulum, Pamekasan \\ ridanmuhtadi@gmail.com
}

\begin{abstract}
The Industrial Revolution Era 4.0 had a major impact on the life of a country. All nations are required to face this era with all the possibilities that exist. Indonesia wants to be able to compete globally, especially in the economic field. Millennial generation is considered capable of making this country more prosperous and advanced with all its characteristics, including santri. Millennial santri actually can also take part in economic growth in the Industrial Revolution 4.0 era, which is increasingly heavy competition. Through the power of MSMEs, santri and pesantren must have enormous potential in the government's big agenda, namely Indonesia 4.0. The potential for developing MSMEs can be felt more quickly if their development is supported by quality human resources and the provision of supporting facilities. Marketing training, working together with e-commerce platforms, internet procurement and supporting electronic devices, as well as network expansion to private companies and SOEs are steps that can be taken to encourage the growth of pesantren MSMEs. Through MSMEs, santri and pesantren are able to improve the country's economy but still uphold Islamic principles.
\end{abstract}

Keywords: Santri, Millennial, Industrial Revolution 4.0, UMKM 


\section{Background}

The Industrial Revolution 4.0 can bring considerable changes in all areas of life. Because by the meaning of language in the Big Indonesian Dictionary (KBBI) the Industrial Revolution is a change that is very fast in the order of business implementation of the production process. ${ }^{1} \mathrm{~A}$ country must be able to remain upright in facing all challenges in this 4.0 era and all the possibilities that exist. ${ }^{2}$ This is also felt by Indonesia. The government also set 10 strategic steps in the Making Indonesia 4.0 agenda. All of that was done to be able to face a new chapter of the times but still be able to compete at the international level. Indonesia's optimism with the 4.0 Industrial Revolution will bring Indonesia into the top 10 countries with the highest economy in the World. ${ }^{3}$ This nation also hopes greatly for its generation to be able to bring this country towards these ideals. The generation in question is the millennial generation that was born in the era of technology and the internet to become an inseparable part of life, and that is what was brought about by the Industrial Revolution. ${ }^{4}$ Like it or not, a generation of mileniallah is able to realize the hopes of the nation. Millennial generation has very close characteristics. One of them is not far from technology and the internet. These characteristics are also evident in the students, those who are currently or have taken education in pesantren. The religious educational background was in fact able to provide its own color for the students as agents of national change. With all the challenges of the times, students are still able to stand firm without leaving religious teachings.

One aspect that gets more attention is the economy. After all, a country can be said to be advanced if the economy is also advanced. The next generation of the nation also gets a tough task, which is to bring the nation's economy to compete globally. That was also the case with the students. Then, can the students who have been considered only experts in the field of religion be able to show their fangs to bring the nation's economy to be better? This paper reveals how students are able to contribute to the progress of the nation's economy. Pesantren as a place for students to learn will also be discussed in this simple paper. Through the discussion in this essay, the writer wants to reveal that students and pesantren basically have extraordinary

\footnotetext{
${ }^{1}$ Kamus Besar Bahasa Indonesia (KBBI)

${ }^{2}$ https://www.i- scoop.eu/industry-4-0/ (Accessed on 4 Oktober 2019)

${ }^{3}$ S. Priatmoko, "Memperkuat Eksistensi Pendidikan Islam Di Era 4.0

${ }^{4}$ Strauss, W., \& Howe, N. (1991). Generations: The History of America's Future, 1584 to 2069. New York, London, Toronto, Sydney: Harper Parennial.
} 
potential in developing the nation's economy.

\section{Research Method}

Research Method used is method descriptive qualitative study based on literature. The aim to explain and describe in more detail about $t$ main objective of the study is that the opportunities and challenges faced by the boarding school entered the era of the Industrial Revolution 4.0. The analysis carried out seeks to explain the potential of Santri in the face of the Industrial Revolution 4.0 by revealing field data and supported by supporting literature.

\section{Discussion}

Change and development of the times become something that can not be avoided. It is the duty of humans to always be able to adjust to changes in being able to function properly as humans. Thus, he was able to achieve the initial goal created, namely as khalifatullah fil ardh. Likewise at this time, where most aspects of life can not be separated from the existence of technology and the internet. Even the generation that lives today must be able to stay upright facing this challenge. More than that, Indonesia places great hopes on the nation's millennial generation to be able to bring Indonesia to compete at the international level, especially in terms of the economy.

\section{Santri Millennial}

Talking about millennial, technology and the internet will always be a reference in the topic. The term millennial actually comes from America, where it refers to a generation that is familiar with technology from birth or digital native. As is known, technological developments between America and Indonesia are not the same. The development of technology in Indonesia is far behind 10 years compared to America. Therefore, the use of the standard birth year in terms of millennial generation is inappropriate. In Indonesia, people born in 1996 and above can be called millennial generation. ${ }^{5}$ Millennials are a group of people born where technology and the internet have become an important part of life in that place.

A survey conducted by the Indonesian Internet Service Providers Association (APJII) showed

\footnotetext{
${ }^{5}$ https://www.cnnindonesia.com/nasional/20171021153629-21-249958/melihat-corak-milenial-santri,
} 
that $49.52 \%$ of Indonesian internet users came from millennial generation. ${ }^{6}$ Millennials do most of their activities with technology and the internet. Ranging from shopping, playing games, communicating, making transactions, discussing, to reading and writing can be done only through a device in hand.

Included in the millennial category are also students who are already very familiar with digital technology. In general, santri are people who take Islamic education in a pesantren and usually at the same time reside in the pesantren. However, the understanding of students is not always that narrow. Alumni or pesantren graduates who are no longer studying in pesantren are still considered as santri. Thus, millennial students are people who are currently or have been educated at pesantren, where they are very familiar and skilled in using digital and internet technology.

\section{Industrial Revolution 4.0}

Along with the phenomenon of this lifestyle shift, there emerged the Industrial Revolution 4.0 era which was marked by increased interaction connectivity, the development of information and communication technology, as well as the sophistication of AI robots that further facilitated human work. ${ }^{7}$ The existence of the 4.0 Industrial Revolution certainly has an enormous impact on the survival of a country. The country must be able to follow this development if it does not want to be left behind by other countries. Likewise Indonesia, the 4.0 Industrial Revolution finally made the government have to set concrete steps so that this nation can still compete globally. Making Indonesia 4.0 became a concrete step for the government in welcoming this 4.0 Industrial Revolution. The government has prepared a road map or map of Indonesia's efforts to compete in this era. Road Map Making Indonesia 4.0 is very important so that Indonesia's steps have a clear direction. The road map is reflected in 10 strategic steps. One such step is to empower MSMEs. ${ }^{8}$ MSMEs is expected to be the front guard in developing the people's economy

\footnotetext{
${ }^{6}$ https://kumparan.com/@kumparantech/generasi-millenial-dominasi-pengguna-internet-di-indonesia,

${ }^{7}$ http://www.kemenperin.go.id/artikel/18967/Making-Indonesia-4.0:-Strategi-RI-Masuki-Revolusi- Industri-Ke-4, accessed on pada 22 Oktober 2019

${ }^{8}$ https://bisnis.tempo.co/read/1083569/10-strategi-pemerintah-hadapi-revolusi-industri-4-0/full\&view=ok, accessed on pada 22 Oktober 2019
} 


\section{The Role Of Santri For Msmes}

MSME is the backbone of the economy in ASEAN and Indonesia. Around $88.8 \%$ to 99.9\% of economic business forms in ASEAN are MSMEs. Job absorption through MSMEs reached $51.7 \%$ to $97.2 \%$. This business has a share of $99.99 \%$ of the total business

actors in Indonesia or as many as 56.54 million units. Therefore, SMEs have enormous potential in developing the Indonesian economy. ${ }^{9}$

MSMEs can come from anywhere, from parents to young people who are included in millennials. It is at this point that millennials actually have a great opportunity to participate in developing Indonesia's economy. Coupled with his expertise in using a variety of technologies and high creative power, MSMEs run by millennials will be able to develop the country's economy. This is increasingly supported by the large number of millennials in Indonesia reaching 90 million people, ${ }^{10}$ among them are students who are currently or have been educated at pesantren.

Based on data from the Ministry of Religion, the number of Islamic boarding schools currently reaches 27,290 units with a total number of students of 3,876,696 people. ${ }^{11}$ This large amount must be balanced by maximizing economic activities in each pesantren, such as the procurement of pesantren cooperatives or Kopontren. That is also being promoted by the Minister of Industry, Airlangga Hartanto. ${ }^{12}$ Deputy for Financing, Kemenkop and UKM, Yuana Sutyowatu stated that pesantren have three strategic roles. First, as a pesantren business institution that conducts business in the consumption, ordering, production, service or savings and loan sectors in order to meet the needs and achieve the independence of the pesantren and business development. Secondly, the role of pesantren in the economy can be carried out through incubating the santri business. Islamic boarding schools become santri business laboratories in order to give birth to Muslim entrepreneurs who fight for the Islamic economy in Indonesia. Third, pesantren as a local business center by involving the community to develop

\footnotetext{
${ }^{9}$ https://www.jurnal.id/id/blog/2017-perbedaan-umkm-perkembangannya-di-indonesia/, accessed on pada 24 Oktober 2019

${ }^{10} \mathrm{https}: / / w w w . i n e w s . i d / f i n a n c e / r e a d / 56521 /$ bappenas-jumlah-milenial-di-indonesia-capai-90-juta-orang, accessed on pada 24 Oktober 2019

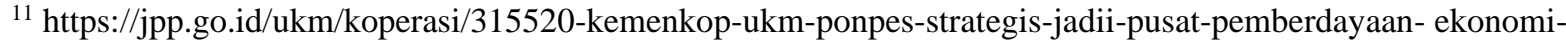
umat, accessed on pada 25 Oktober 2019

12 https://news.detik.com/berita-jawa-tengah/d-4053295/kementerian-perindustrian-akan-kembali- galakkankopontren, accessed on pada 24 Oktober 2019 pukul 10.00 WIB.
} 
local resources as a regional superior product. ${ }^{13}$

Some pesantren that have carried out activities in the economic sector include Maslakhul Huda Islamic Boarding School Margoyoso Pati. This pesantren drives economic activities with the community as seen in the established institutions. These institutions are Non-Governmental Development Institutions (LSPM), and Savings and Loans Joint Business Units (UBSP) or Kopontren that focus on the economy. Likewise, the Pondok Pesantren Sidogiri Pasuruan which has developed a model of Islamic boarding schools based on pesantren. ${ }^{14}$

The choice of what type of economic business to be developed actually lies in the potential of each pesantren and adapts to its characteristics, and so does if the santri want to establish their own business. There are four major groups regarding the types of economic businesses that can be developed by pesantren. The four types of businesses are agribusiness (agriculture, fisheries, and plantations), services (KBIH, printing, Lazis, BMT, and cooperatives), trade (retail, shops, sales agents), and industry (water purification, furniture). Therefore, before determining what economic businesses are suitable for implementation, it is necessary to do a mapping together with the community regarding local potentials and needs.

Awareness of the importance of entrepreneurship has in fact led to a movement of the santri. The establishment of HIPSI (Indonesian Santri Entrepreneurs Association) on October 3 , 2012 at Al-Yasini Islamic Boarding School Pasuruan signaled the turmoil of the students to participate in developing the nation's economy. This organization was founded with the vision of printing entrepreneurs who have a moral mercy. ${ }^{15}$ This extraordinary potential has in fact been captured by Sandiaga Uno who was preparing students to face the Indonesian Revolution 4.0 by bringing up the term "Santripreneur". ${ }^{16}$ Santripreneur is a program that encourages students to be involved as entrepreneurs in business.

\section{Synergy of SMEs Santri with the E-Commerce Platform}

One of the crucial obstacles in building a pesantren economy is networking. This issue concerns how to maximize the network that comes from the popularity of the kyai, alumni

13 https://jpp.go.id/ukm/koperasi/315520-kemenkop-ukm-ponpes-strategis-jadii-pusat-pemberdayaan- ekonomiumat, accessed on pada 24 Oktober 2019 pukul 18.30 WIB.

${ }^{14}$ Choirul Fuad Yusuf \& Suwito NS, et al, Model Pengembangan Ekonomi Pesantren, hlm 12-13.

${ }^{15} \mathrm{https} / / /$ hipsi.or.id/index.php/page/pengurus, accessed on pada 25Oktober 2019 pukul $21.00 \mathrm{WIB}$

16 https://akurat.co/ekonomi/id-359680-read-sandiaga-gerakan-santripreneur-untuk-hadapi-revolusi- industri-40, accessed on pada 25 Oktober 2019 pukul 21.40 WIB. 
network, and the pesantren network with the community. ${ }^{17}$ The same thing alsohappened with students who wanted to set up their own businesses. When capital and products already exist, marketing becomes something that should not be forgotten, especially in Islamic boarding schools that have homemade products. Chairman of Rabitah Ma'ahid Islamiyah Nahdlatul Ulama, Abdul Ghofarrozin revealed that actually many products made by santri in Islamic boarding schools have the potential to be developed and are no less good in quality than factory-made. However, the boarding school is often constrained by marketing problems. ${ }^{18}$ As a result, the products of the students cannot be widely sold, only within the boarding school and around the boarding school.

One of the efforts that can be done to further develop students' UMKM is to use an online platform to promote these MSME products. This is where the role of government and other economic actors is needed. The government should be able to facilitate the marketing needs of students' products, both from marketing expertise or the use of a wider network. Other economic actors, such as e-commerce, can also participate in helping to market the sanri MSME products. This has actually been done by Bukalapak who conducts online business training at Bahrul Ulum Islamic Boarding School in Jombang. The activity is a series of economic empowerment programs for Muslim communities in Indonesia. ${ }^{19}$

The idea of marketing pesantren MSME products that are run by santri through ecommerce certainly must be balanced with the provision of facilities such as the internet and communication tools. This becomes a problem in itself if the pesantren previously did not have supporting facilities, considering that the pesantren had indeed limited its students to use communication tools, especially gadgets. This is where the role of government is also highly expected. Procurement of this facility does not mean that it will disrupt the learning process in the pesantren, but its use is of course the permission of the clerics or boarding school administrators and adjusted to the needs.

\footnotetext{
${ }^{17}$ Irul Fuad Yusuf \& Suwito NS, et al, Model Pengembangan Ekonomi Pesantren, hlm 14.

18 https://akurat.co/news/id-343147-read-dinilai-berkualitas-produkproduk-buatan-santri-pondok-pesantrenterkendala-pemasaran, accessed on pada 26 Oktober 2019 pukul $09.10 \mathrm{WIB}$.

${ }^{19}$ https://www.republika.co.id/berita/dunia-islam/islam-nusantara/18/05/05/p889yy335-bukalapak-kerja- samadengan-pesantren-dorong-ukm, accessed on pada 26 Oktober 2019 pukul 07.45 WIB.
} 


\section{Conclusion}

Facing the Industrial Revolution 4.0 things that santri can do to participate in building the nation's economy is through MSMEs. Islamic boarding schools and students can conduct economic business in the field of agribusiness, services, trade, and industry, adjusted to the potential of natural and human resources. Marketing of MSME results is also important. Marketing training, collaborating with e-commerce platforms, procurement of supporting facilities, are very much needed in the development process of UMKM Pesantren. which in turn can support the achievement of Indonesia's target in the face of the Industrial Revolution 4.0, which is to become the top 10 countries with the highest economy in the World.

\section{Suggestion}

With the great potential of students in improving the Indonesian economy, students should be optimistic about this. By continuing to try to improve skills and knowledge, especially to develop SMEs, which is one of the strategic steps in the face of the Industrial Revolution 4.0. This can be optimized by synergizing the pesantren's MSME with the $e$-commerce platform . So that Indonesia's target to become the top 10 countries with the highest economy in the World can be realized. 


\section{Daftar Pustaka}

4.0. from https://www.i-scoop.eu/industry-4-0/

http://www.kemenperin.go.id/artikel/18967/Making-Indonesia-4.0:-Strategi-RI-Enter- RevolusiIndustri-Ke-4, accessed on 22 October 2019 at 09.10 WIB.

https://akurat.co/ekonomi/id-359680-read-sandiaga- movement-santripreneur-for-hoperevolution-industri-40, accessed on 25 October 2019 at 21:40 WIB

https://akurat.co/news/id-343147-read-inilai-berkualitas-produkproduk-buatan-santri-pondokpesantren-terkendala-marketing, accessed on 26 October 2019 at 09.10 WIB.

https://bisnis.tempo.co/read/1083569/10-strategipemerintah-cope-revolution-industri-40/full\&view=ok , accessed on October 22,2019 at 09.45 WIB.

https://goukm.id/apa-itu-ukm-umkm-startup/, accessed on 24 October 2019 at 16.19 WIB https://hipsi.or.id/index.php/page/pengurus , accessed on 25 October 2019 at 21:00 WIB

https://jpp.go.id/ukm/koperasi/315520-kemenkop-ukm-ponpes-strategic-jadii-pusat- pember empower-ekonomi-umat, accessed on 25 October 2019 at 08.00 WIB.

https://jpp.go.id/ukm/koperasi/315520-kemenkop-ukm-ponpes-strategic-jadii-pusat- pember empowerment-ekonomi-umat, accessed on 24 October 2019 at 18:30 WIB.

https://kumparan.com/@ kumparantech/generasi-millenial-dominasi-penguser-internet-diindonesia, accessed on 22 October 2019 at 09.13 WIB.

https://news.detik.com/berita-jawa-tengah/d-4053295/k Ministry-perindustrian-akan-kambatgalakkan-kopontren, accessed on 24 October 2019 at 10:00 WIB.

https://www.cnnindonesia.com/nasional/20171021153629-21-249958/melihat-corak-milenialsantri ,.

https://www.inews.id/finance/read/56521/bappenas-jotal-milenial-di-indonesia-capai-90-jutaorang, accessed on 24 October 2019 at 13.00 WIB.

https://www.jurnal.id/id/blog/2017-perbariasi-umkm-perkembangannya-di-indonesia/ , accessed on 24 October 2019 at 17.00 WIB.

https://www.republika.co.id/berita/dunia-islam/islam-nusantara/18/05/05/p889yy335- bukalapakkerja-sama-dengan-pesantren-dorong-ukm , accessed on 26 October 2019 at 07:45 WIB.i-scoop. (2018). Industry 4.0: the fourth industrial revolution - guide to Industrie 
Joseph,Choirul Fuad and NS, Suwito, et al.2010. Pesantren Economic Development Model. Purwokerto: STAIN Purwokerto Press ,.

Priatmoko. 2018. "Strengthening the Existence of Islamic Education in Era 4.0," TA'LIM J. Stud. Educator Islam, vol. 1, no. 2.

Strauss, W., \& Howe, N. 1991. Generations: The History of America's Future, 1584 to 2069 . New York, London, Toronto, Sydney: Harper Parennial ,. 